\title{
The Future of Public Employee Retirement Systems
}

EDITED BY

Olivia S. Mitchell and Gary Anderson 


\section{OXFORD \\ UNIVERSITY PRESS}

Great Clarendon Street, Oxford ox2 6DP

Oxford University Press is a department of the University of Oxford.

It furthers the University's objective of excellence in research, scholarship,

and education by publishing worldwide in

$$
\text { Oxford New York }
$$

Auckland Cape Town Dar es Salaam Hong Kong Karachi

Kuala Lumpur Madrid Melbourne Mexico City Nairobi

New Delhi Shanghai Taipei Toronto

With offices in

Argentina Austria Brazil Chile Czech Republic France Greece

Guatemala Hungary Italy Japan Poland Portugal Singapore

South Korea Switzerland Thailand Turkey Ukraine Vietnam

Oxford is a registered trade mark of Oxford University Press in the UK and in certain other countries

Published in the United States

by Oxford University Press Inc., New York

(C) Pension Research Council, The Wharton School, University of Pennsylvania, 2009

The moral rights of the authors have been asserted

Database right Oxford University Press (maker)

First published 2009

All rights reserved. No part of this publication may be reproduced, stored in a retrieval system, or transmitted, in any form or by any means, without the prior permission in writing of Oxford University Press, or as expressly permitted by law, or under terms agreed with the appropriate reprographics rights organization. Enquiries concerning reproduction outside the scope of the above should be sent to the Rights Department, Oxford University Press, at the address above

You must not circulate this book in any other binding or cover and you must impose the same condition on any acquirer

British Library Cataloguing in Publication Data

$$
\text { Data available }
$$

Library of Congress Cataloging in Publication Data

$$
\text { Data available }
$$

Typeset by SPI Publisher Services, Pondicherry, India Printed in Great Britain on acid-free paper by

MPG Books Group, Bodmin and King's Lynn

ISBN 978-0-19-957334-9 


\title{
Chapter 7
}

\section{Administrative Costs of State Defined Benefit and Defined Contribution Systems}

\author{
Edwin C. Hustead
}

In the private sector, the relative administrative costs of defined benefit (DB) and defined contribution (DC) systems can have a major impact on the decision to select one plan over the other. This chapter examines the administrative costs of the two types of plans in the public sector and their potential impact on the type of plan selected by a public sector employer. We begin with a comparison of DB and DC administrative expenses for the Federal government and for seven state-wide plans. We then discuss the impact that administrative expenses might have on the choice of a plan and other reasons that might impact on a choice between the two types of plans.

\section{Prior studies}

My previous paper (Hustead 1998) on administrative expenses in private sector pensions showed that annual administrative expenses for DB plans (3.1\% of payroll) were twice those of DC plans $(1.4 \%$ of payroll) for employers with only 15 employees. This was one of several reasons that might lead small employers to adopt a DC plan instead of a DB plan. The DC advantage in administrative expenses also held for large private sector employers but the difference was smaller. For instance, for employers with 10,000 employees, the administrative expenses for DB plans were 0.23 percent of payroll compared to 0.16 percent for the same size DC plans. Such a relatively small difference as a percentage of payroll would not have been a major factor in deciding between a DB and a DC plan. For comparison with measures used in this chapter, it is reasonable to consider the administrative expenses of large private sector plans to be around 2 percent of plan contributions for employers of 10,000 employees because private sector plan contributions are usually less than 10 percent of payroll.

Most state-wide public plans include many more than 10,000 employees and almost all public employers already have a DB plan, so the impact of administrative expenses in the public sector is much different. Public employers tend to confront one of two questions when considering 


\section{Edwin C. Hustead}

adoption of a DC plan. First, and by far the most common, is whether to supplement the pre-existing DB plan with a DC plan. Second, some employers consider whether to replace the DB plan with a DC plan. As a practical matter, this second consideration tends to be limited to future employees and current employees who elect the DC plan.

\section{Administrative costs of state and Federal retirement plans}

This chapter uses two measures of administrative expenses. One is as a percentage of average plan assets, and the other is as a percentage of employee and employer contributions. Table $7-1$ shows the amount of administrative expenses and the two measures for seven states that have both a DC and a DB plan. Two measures are used because one or the other can be problematic in some situations. Most importantly, the employer contribution to a DB plan can fluctuate widely in response to economic conditions. These seven states, and most other states, have a separate agency that administers the pension plans. The data were derived from the most recent audited financial statements posted on the Web sites of the administering agency. Table 7-1 is followed by a brief summary of the plans available in each state. This includes information on the name of the report, fiscal year, and administrating agency.

We summarize the state plan structures as follows:

- The Florida Retirement System administers two DB plans for most employees. Employees have been offered a DC plan as an alternative to the DB plans since 2002. There are also DC plans for specific groups. As of 2007, there were 680,000 employees in the primary DB plan and 82,000 members in the DC plans. Financial results are for the fiscal year ending June 30, 2007.

- The Ohio Public Employees Retirement Systems has offered two alternatives to the traditional DB plan since 2003; one of these is a DC plan and the other is a combined DB/DC plan. As of 2006, 369,000 employees were in the traditional DB plan, 5,600 in the DC plan, and 6,100 in the combined DB/DC plan. Data are for the year ending December 31, 2006. Public employees in Oregon are in a DB plan administered by the Oregon Public Employees Retirement System. Since 2004, the employee contributions have been deposited in a DC plan so all members are in both a DB and a DC plan. Data are for the year ending June 30, 2007.

- Colorado employees are covered by a DB plan and can make voluntary contributions to a DC plan. The plan is administered by the Colorado 
7 / Administrative Costs of State

TABLE 7-1 Annual administrative expenses for state retirement plans as a percentage of contributions and assets

\begin{tabular}{lccc}
\hline $\begin{array}{l}\text { State and type } \begin{array}{l}\text { of plan } \\
\text { Flministrative }\end{array} \\
\text { Expenses (millions } \\
\text { of dollars) }\end{array}$ & \begin{tabular}{c} 
Administrative Expenses as a Percentage of \\
\cline { 3 - 4 }
\end{tabular} & $\begin{array}{c}\text { Employee/employer } \\
\text { contributions in year }\end{array}$ & Average Assets \\
Florida DC & 16.1 & 0.53 & 0.01 \\
Ohio DB & 0.15 & 0.07 & $\mathrm{~N} / \mathrm{A}$ \\
Ohio DB/DC & 44.9 & 2.07 & 0.07 \\
Ohio DC & 4.5 & 12.86 & 4.84 \\
Oregon DB & 3.9 & 11.94 & 5.51 \\
Oregon DC & 35.6 & 5.83 & 0.06 \\
Colorado DB & 7.3 & 1.66 & 0.16 \\
Colorado DC & 20.7 & 2.02 & 0.06 \\
Montana DB & 4.3 & 2.33 & 0.34 \\
Montana DC & 2.9 & 0.64 & 0.09 \\
North Dakota DB & 0.4 & 1.87 & 0.16 \\
North Dakota DC & 1.0 & 2.42 & 0.10 \\
West Virginia DB & 0.01 & 0.78 & 0.26 \\
West Virginia DC & 3.0 & 0.19 & 0.10 \\
\hline
\end{tabular}

Sources: Author's computations from data provided to the author by the Florida Retirement System, Ohio Public Employees Retirement Systems, Oregon Public Employees Retirement System, Colorado Public Employees' Retirement Association, Montana Public Employees' Retirement Board, North Dakota Public Employees Retirement System, and the West Virginia Consolidated Public Retirement Board.

Public Employees' Retirement Association and the data are for the year ending December 31, 2005.

- Montana has a traditional DB plan and an optional DC plan. Employees hired after 2002 have had the option of joining either plan. The plan is administered by the Public Employees' Retirement Board. Data are for the year ending June 30, 2006.

- The North Dakota Public Employees Retirement System began as a DC plan in 1966 and was changed to a DB plan in 1977. An optional DC plan was established in 2000 for some employees. Data are for the year ending June 30, 2006.

- Teachers in West Virginia hired before July 1, 1991 are covered by a DB plan and those hired after that date are covered by a DC plan. As of June 30, 2004, there were 19,000 teachers in the DB plan and 21,300 in the DC plan. The plans are administered by the West Virginia Consolidated Public Retirement Board and financial data are for the year ending June 30, 2007. 
By most of the measures, the DC plan administrative expense percentages are larger than those of the DB plans in Table 7-1. This is partly explained by the fact that the DB plans have been established for a much longer time and are much larger than the DC plans. Some of the differences may also be related to the accounting methods used to allocate administrative costs. In some cases, costs may be based on a detailed functional study of costs. In other cases, rough allocations of line items may be used. For example, it is very unlikely that the functional costs of a free-standing DC plan for North Dakota would be less than $\$ 10,000$. The cost of DC plans that are added to the responsibilities of an existing agency are undoubtedly much lower than they would be if there was no agency already administering a DB plan.

Table 7-1 also shows that administrative expenses for a large state-wide plan are relatively small. The state-wide DB plans administrative costs are all 0.1 percent or less of assets. DC plan expenses are higher but all of these plans are much smaller than the DB plans in the same state.

Table 7-1 focuses exclusively on state-wide plans. In many states municipal and county plans also participate in the state-wide plans. Large independent city and county plans would be expected to have similar results to the state plans. Smaller independent city and county plans probably have expenses that are much greater as a percentage of assets for both DB and DC plans because of their size.

The Federal Employees Retirement System (FERS), established in 1986, includes both a DB plan and a DC plan. The Federal government set up a separate administrating agency when it established the Thrift Savings Plan (TSP) as part of the new Federal Employees Retirement System to administer the DB plan. The TSP has grown very large over the years and now holds almost $\$ 200$ billion in assets. Table 7-2 compares the administrative costs of the Federal DB and DC plans. ${ }^{1}$ As would be expected, the costs are quite small as percentages of contributions or assets. Administrative costs are somewhat higher for the TSP but the administrative expenses of both plans are less than 0.05 percent of the assets. One reason that the DB plan costs are so low is that the DB funds have to be invested in special issues, so there is no need for the types of investment decisions and costs that are borne by state plans.

\section{Other expenses}

Two types of administrative expenses are not included in the tables because they are not readily available. One of these is the administrative expense incurred by the employing agencies in collecting the contributions by the employees, which are then forwarded to the pension plan administrative 
7 / Administrative Costs of State

TABle 7-2 Administrative expenses of Federal plans

\begin{tabular}{lcc}
\hline & $\begin{array}{c}\text { Defined Benefit Plans } \\
\text { CSRS/FERS for the year } \\
\text { ended September 30, 2006 }\end{array}$ & $\begin{array}{c}\text { Defined Contribution Plan } \\
\text { Federal Thrift Savings Plan } \\
\text { for the year ended } \\
\text { December 31, 2006 }\end{array}$ \\
\hline $\begin{array}{l}\text { Administrative expenses in } \\
\text { year }(\$)\end{array}$ & 142 & 81 \\
$\begin{array}{c}\text { Employer/employee } \\
\text { contributions in year }(\$)\end{array}$ & 50,300 & 19,601 \\
$\begin{array}{l}\text { Average assets }(\$) \\
\text { Administrative expenses as } \\
\text { a percent of } \\
\text { contributions }(\%)\end{array}$ & 680,500 & 189,942 \\
$\begin{array}{l}\text { Administrative expenses as } \\
\text { percent of average assets } \\
(\%)\end{array}$ & 0.28 & 0.41 \\
\hline
\end{tabular}

Note: CSRS is the Civil Service Retirement System and FERS is the Federal Employees Retirement System. Amounts in millions of US dollars.

Sources: Author's compilation of data from Federal Office of Personnel Management (2007) and Federal Thrift Savings Plan (2008).

agency. Since all of the DB plans in the two tables are contributory, this administrative cost is probably about the same for both types of plans. The other type of expense not included is the charge made by the organizations that invest the DB and DC funds. These charges are usually deducted from the investment earnings. Bauer and Frehen (2008) and French (2008) provide some analysis of the relative administrative expense of public DB and DC expenses.

\section{Organizational structure}

Tables 7-1 and 7-2 show that public plan administrative expenses are generally a small percentage of the assets of each of the retirement systems. In general, this is true of both DB and DC plans. This consistently low level can be explained by the administrative organizations of the state retirement funds. Most state retirement plans tend to have several functional areas, including collection of employee contributions, determination of benefits, payment of retiree benefits, investment management, and information technology. Some of the functions are more extensive for DB plans and others for DC plans but the overall size and cost of the agency would be about the same for either a DB or a DC plan. 


\section{Edwin C. Hustead}

Since most public plans, including all of those in Tables 7-1 and 7-2, are contributory, there must be a process to collect and track contributions from employees and their agencies. This function is larger for DC plans because of the need to direct the contributions to the appropriate funds and to track and report on those funds. The determination of benefits for separating employees is similar in scope for both DB and DC plans. The individual calculations for retirees are very complex for a DB plan. However, the individual determinations and communication of options is much greater for the DC plans for those who have not reached retirement eligibility. The retiree benefit payment and communication is much greater for the DB plans since the function is not necessary for those employees who remove their funds from the state plans at termination.

The investment operation is greater for DB plans since the office must carefully determine and track investment policy for the funds. However, this is also a major function for DC plans since the office has to select the options and monitor the investment options for employees. The information technology function would be similar in scope and detail for both the DB and DC plans.

\section{Trends in DB/DC plans in the public sector}

A report by the National Conference of State Legislators (NCSL 2005) summarized the number and type of state DC plans, and it found that were only three systems that had DC plans as the primary plan for new employees, while none had the DC plan as primary for employees working at the time the DC plan was adopted. The first such plan was for the District of Columbia employees in 1987. This was followed by a change to a DC plan for newly hired West Virginia teachers in 1991 and Michigan state employees in 1997. Six state systems offered a choice of a DB or a DC plan. Four other states direct employee contributions to a DC plan and employer contributions to a DB plan.

There are approximately 100 state-wide plans in the United States. The typical state has a plan for teachers and another for employees. Only three of these plans are primary DC plans and even those continue to maintain a DB plan for employees hired before the adoption of the DC plan. This is in sharp contrast to the private sector where the large majority of plans is DC plans.

\section{Conclusion}

If a large private sector employer were to consider putting all employees in either a DC plan or a DB plan, then the employer could anticipate 
that administrative expenses would be very low relative to plan assets or contributions. Based on the information provided in Tables 7-1 and 7-2, a large state plan of either type would probably have administrative costs of around 0.1 percent of assets per year.

In practice, however, almost all states have existing DB plans, so large public plans are not faced with a choice between the two types of plans. Rather, states are often faced with the choice of whether or not to add a supplemental DC plan to the DB plan or move to a DC plan. The choice is made easier because the administrative costs of the new plan will be small when the function is assigned to the agency that administers the DB plan.

In many states, there have been proposals to completely replace the existing DB plan with a DC plan, at least for new employees. If that were done, there would be a short-term increase in administrative costs to introduce the DC plan, but ultimately the administrative costs would drop to levels near those for a DB-only plan. Since administrative costs are a small percentage of assets or contributions the long-term administrative costs do not affect the decision of whether or not to adopt a DC plan to replace the DB plan. The short-term costs of introducing the plan do have to be considered but even these are only a small part of the total long-term cost of the DC plan.

Perhaps the greatest deterrent to adoption of a DC plan is that it may not be feasible, or sometimes even legal, for a public employer to replace a DB plan by a DC plan for existing employees' future service. Many states including Pennsylvania have a legal prohibition against reducing benefits for existing employees' future service. DC plans distribute benefits differently from DB plans, so even though some employees would receive greater benefits with a DC plan, there would be a class of employees who would receive lower benefits in a $\mathrm{DC}$ plan.

In states with a legal prohibition against changing benefits for current employees, it would be expected that the class of employees with lower benefits would succeed in overturning a DC plan for their future service through the courts. In states without such a legal prohibition, there is strong, and usually successful, opposition to changing future benefits for existing employees. This opposition includes employee unions as well as legislators who are often covered by the existing retirement plan.

Private sector employers who have moved from DB to DC plans have often done so because they would achieve immediate and substantial savings. Without the ability to change plans for current employees, that opportunity is generally not open for public sector employees. In fact, moving from a DB plan to a DC plan for public sector employers under these conditions might result in a substantial increase in contributions in the short run. 


\section{Edwin C. Hustead}

\section{Notes}

1 Administrative expenses for the Civil Service Retirement System/Federal Employee Retirement System (CSRS/FERS) plan were obtained from the Office of the Actuaries of the Federal Office of Personnel Management. The remaining data in Table 7-2 are derived from annual reports of the CSRS/FERS and the Federal Thrift Savings Plan (TSP) administrators.

\section{References}

Bauer, Rob and Rik Frehen (2008). 'The Performance of US Pension Funds.' SSRN Working Paper. Rochester, NY: Social Science Electronic Publishing.

Federal Office of Personnel Management (2007). Civil Service Retirement and Disability Fund Report for the Fiscal Year ended September 30, 2007. Washington, DC: Office of Actuaries of the US Office of Personnel Management.

Federal Thrift Savings Plan (2008). 'Statement of Net Assets and Changes in Assets for 2005 and 2006.' Birmingham, AL: The Federal Retirement Thrift Investment Board. www.tsp.gov.

French, Kenneth R. (2008). 'The Cost of Active Investing.' SSRN Working Paper. Rochester, NY: Social Science Electronic Publishing.

Hustead, Edwin C. (1998). 'Trends in Retirement Income Plan Administrative Expenses' in O.S. Mitchell and S. J. Schieber, eds., Living with Defined Contribution Plans. Philadelphia, PA: University of Pennsylvania Press, pp. 166-78.

National Conference of State Legislatures (NCSL) (2005). 'Defined Benefit and Defined Contribution Retirement Plans.' Denver, CO: National Conference of State Legislatures. www.ncsl.org/programs/fiscal/defineretire.htm. 